\title{
Digitalization and Banking Crisis: A Nonlinear Relationship?
}

\author{
Mohamed Sami Ben Ali $^{1}$ (D)
}

Accepted: 14 February 2022 / Published online: 3 March 2022

(c) The Author(s) 2022

\begin{abstract}
This study assesses the impact that ICT can have on the occurrence of banking crisis for a sample of 113 countries over the period 1996-2017 while considering the interfering role of corruption and the potential existence of a nonlinear relationship for the ICT-banking crisis nexus. We consider countries with varying income levels to check for the stability of the relationship. Our estimation results show that more highly ICT endowed countries can improve the resilience of the banking system. The study provides evidence that ICTs do not produce the same effect regardless of a country's level of income. Estimation outcomes show the existence of a threshold effect driving the ICT-banking stability nexus. More results show that Information and communication technologies can improve the stability of the banking system only when corruption is relatively low. However, when corruption is endemic, ICT endowment is useless for the stability of the banking system.
\end{abstract}

Keywords ICT $\cdot$ Corruption $\cdot$ Crisis $\cdot$ Banking stability

JEL C54 $\cdot$ E5 $1 \cdot$ G28

\section{Introduction}

The term ICTs or, in full, information and communication technologies, refers to all tools, devices, networks and social media that are intended to help people communicate and to disseminate information. ICTs are nowadays present all over the world. As computers, smartphones and social media are now a part of people's daily lives (Drezner and Farrell 2008).

There is now a worldwide race to improve national infrastructure and increase access to all kinds of information and communication technologies. There are two

Mohamed Sami Ben Ali

msbenali@qu.edu.qa

1 Department of Finance and Economics, College of Business \& Economics, Qatar University, P.O. Box: 2713, Doha, Qatar 
main reasons for this growth in interest as ICTs now play a decisive role in different facets of the lives of a country's citizens.

From the purely political aspect, ICTs are now regarded as the new driver of the third wave of democratization (Ben Ali 2020). Indeed, access to ICT can make it easier to broadcast information and thus discourage politicians from making false statements during electoral campaigns. Obviously, freedom of expression and democracy are conditioned by access to ICTs (Balkin 2004). Moreover, many governmental services are now provided through e-government platforms, which can increase the transparency and accountability of governments.

From an economic perspective, a pioneer study by Hardy (1980) showed the vital role of the telephone in economic activity in general. Indeed, ICTs can have an impact on different economic sides. According to Wang and Li (2017), cross-country differences in ICT can impact international trade and are associated with differences in export performance. Indeed, a $1 \%$ increase in the ICT development index increases industry export performance by $10 \%$. Countries' endowments in ICTs can also help improve economic growth potentialities. In a study by Hwanga and Shinb (2017), the authors show that ICTs improve growth potentialities in Korea through embodied technology in intermediate inputs and investment goods. According to the authors, sustainable growth in that country requires more investment in information and communication technologies. The same results have been documented for a sample of 59 countries for the period 1995-2010 (Niebel 2018). The author shows in this study that developing, emerging, and developed economies all gain from information and communication technologies. Edquist and Henreksonb (2017) find similar results for the Swedish economy. They consider a sample of 47 different industries for the period 1993-2012 and show that ICTs are associated with valueadded growth in the Swedish business sector. Similarly, Jin and Moon Cho (2015) argue that IT infrastructure, IT competence, IT investment and IT trade size mediate ICT capacity's effects on economic growth and affect economic development.

Beyond traditional economic issues, it has been shown in the literature that ICT use can impact several aspects of the economy. For example, the empirical studies show that ICT use significantly stimulates CO2 emissions (Avoma et al. 2020). It was also evidenced that ICTs reduce poverty and inequality when used as instruments for financial inclusion (Mushtaqa and Bruneau 2019; Tchamyoua et al. 2019). Literature findings show also that the segmentation by product complexity is more sensitive to internet use than segmenting by level of income, and that countries trade more if similar levels of ICT use are coupled with similar degrees of product complexity in the trading countries (Rodríguez-Crespoa and Martínez-Zarzoso 2019).

As far as ICTs are concerned, one can examine the potential role of ICTs on banking activity. In all countries, banks play a major role in channeling saving to investment. Moreover, a clear positive relationship show that the banking system contributes to countries' economic growth (Demirguc-Kunt and Levine 2001) as credit represents the major source of financing for most small and medium enterprises. Lack of banking credit is therefore detrimental to economic growth. At the same time, researchers and policymakers argue that financial crises did not happen exclusively because of exogenous factors and that other interfering channels might 
have affected the performance. Specifically, the institutional factors were pointed out as being determinants in these crises (Barth et al. 2007). For example, banks might not intermediate efficiently with a macroeconomic environment of pervasive corruption. Corruption can therefore hinder banking activity and cause losses even to sound banks. This could, for example, happen when bad borrowers with good connections can get finance while good borrowers without connections are rejected for financing even with sound projects (Charumilind et al. 2006). Lending to borrowers who are highly risky but have good connections in the banking system can give rise to higher default rates (La Porta et al. 2003). This has drawn the attention of both policymakers and researchers to the fact that sustained economic growth and economic stability cannot happen without a stable banking system (Fernández et al. 2016).

The main question now is whether, and if so how, more ICT endowment could potentially help reduce banking instability. We specifically suspect the potential interfering impact of corruption in the ICT-banking stability nexus. To the best of our knowledge, there is limited number of papers dealing with the ICT-banking industry (for example Asongu and Biekpe 2018) but very few dealing directly with the impact of ICTs on banking crisis. Our study takes a step in this direction. It tackles this interfering effect of ICTs in the corruption-banking stability relationship and seeks to determine to what extent ICTs can potentially serve as stabilizing effect when a corruption is high. We contribute to the literature in several ways. Firstly, with a large sample of 113 countries, we assess for the first time the potential correlation of information and communication technology with the soundness of banking systems, while shedding light on the interfering effect of corruption in the ICTbanking stability nexus. Second, we consider both linear and nonlinear relationships in order to determine to what extent the implementation of an ICTs infrastructure is important and if a certain level of ICTs provision is required. This is particularly central in poor countries lacking sufficient financial resources.

The rest of the paper is organized as follows. The following section presents the methodology, variables and the data used. The other section presents and discusses the results. The last section concludes and provides some policy implications.

\section{Methodology, Variables and Data}

This study empirically assesses the existence of a correlation between digitalization through ICT adoption and the occurrence of banking crisis. Our dependent variable is the banking Zscore (BZscore), referred to as the main variable in the literature measuring the probability of banking crisis occurrence (Xiping et al. 2020; Lepetit and Frank 2015). Z-score is defined as "the probability of default of a country's banking system, calculated as a weighted average of the z-scores of a country's individual banks (the weights are based on the individual banks' total assets). Therefore, the z-score is calculated as the sum of bank's return on assets and equity to assets ratio divided by the standard deviation of return on assets (Chiaramonte et al. 2016). The Z-score is extensively used in the empirical banking literature to study 
the probability of banking default and crisis (Stewart and Chowdhury 2021; Xiping et al. 2020; Ben Ali et al. 2018; Lepetit and Frank 2015; Lepetit and Strobel 2013; Rojas-Suarez 2001). It is also one of the indicators used by the World Bank for assessing financial institutions' soundness. The Z-score is calculated as the raw score minus the population mean, divided by the population standard deviation. The Z-score reflects the number of standard deviations that a bank's return on assets has to drop below its expected value before equity is depleted and the bank is insolvent, as a proxy for banking risk (Klomp and De Haan 2015). A lower Z score denote a risk of bankruptcy while a higher score suggest a solid financial institution. Our dependent variable is driven by a set of bank-specific, industry-specific and macroeconomic control variables $(X)$, a country specific effect $\left(\alpha_{\mathrm{i}}\right)$ and an error term $\left(\varepsilon_{\mathrm{it}}\right)$ according to the following model:

$$
\text { BZSCore }_{i t}=\alpha_{i}+\gamma_{t}+\beta_{i t} X_{i t}+\delta_{i t} Y_{i t}+\theta_{i t} I C T_{i t}+\varepsilon_{i t}
$$

$X_{\mathrm{it}}$ is a matrix of bank-specific, industry-specific variables. $Y_{\mathrm{it}}$ is a matrix of macroeconomic variables. ICT is information and communication technologies variable. We consider a sample of 113 countries with different levels of income. The list of the countries considered in our sample is presented in Table 6 in the appendix. As reported in Ben Ali et al. (2020), Bank-specific variables are proxied by the following variables: the Net Interest Margin (NIM) used to assess the efficiency of banks' lending activities, the Return on Assets (ROA) used to express banks' profitability, and the Cost to Income ratio (CIR) to take into consideration the cost of the lending activity (Bretschger et al. 2012). The Cost to Income variable is expected to display a negative coefficient which shows that improving banking stability requires better cost management. Profitability is expected to be positively correlated to banking stability since more profitability makes banks more financially stable and resilient to crisis. The Net Interest Margin is also expected to be positively correlated with banking stability, as a high value of this variable means that the banks' strategy earns more than what it costs, leading to more banking stability. The higher the ratio, the more efficient is the banking activity and therefore its stability. Banking industry variables consist of the Concentration Ratio (CONC) (Cubillas and Suarez 2013; Ben Khedir et al. 2010). Two strands of literature assess the effect of banking concentration on banks' stability (Ben Khediri et al. 2010). The first strand shows that more concentration induces more profitability in the banking system and therefore sounder banks. The second argues that more concentration causes banks to engage in riskier activities, creating more non-performing loans and helping to accumulate risky portfolios, and therefore leads to more banking instability. Bank-industry and bank-specific variables are extracted from Laeven and Valencia (2018) and from the Bankscope and Orbis Bank Focus databases.

Three macroeconomic variables are used in our model, represented in the matrix $(Y)$. The first two are the economic growth rate and the inflation rate (Athanasoglu et al. 2008). The economic growth variable is expected to produce a positive effect on banking stability. Indeed, more economic growth should normally induce more banking activity, which should produce better profits for the banks. As regards inflation, its impact on banking stability depends on its impact on profitability. It depends on the 
degree to which bank income and expenses increase relative to operating costs (Athanasoglou et al. 2008). A third macroeconomic variable included in our specification is the level of corruption. When measuring corruption the literature presents three main index or variables. First, World Bank World Governance Indicators (WDI) present the control of corruption index that ranges between -2.5 to 2.5 where a low value of this index represent a corrupted country while a high value represent a clean country. The second index used to measure the corruption, is the Transparency International Corruption Perception Index (CPI) ranging from 0 to 100 where a low value of this index indicates a corruption country and a high value represent a clean country. For availability of the data for our period of study, we use the Control of Corruption index $(C O C)$. Macroeconomic variables (inflation and growth rate) were extracted from the World Bank development indicators database (WDI) while the corruption variable statistics were extracted from the World Bank governance indicators (WGI). As regards ICT variables, we use two main proxies, namely the number of individuals using the internet as a percentage of the population $(I U I)$ and the number of mobile cellular telephone subscriptions per 100 people $(M C S)$. The statistics for this variable were drawn from the International Telecommunication Union (ITU) database. Our descriptive statistics and correlation matrix, presented in Tables 4 and 5, respectively, show that overall our variables of interest show the expected coefficients. For example, they show a negative correlation between the cost to income ratio and the banking stability variable. In addition, they display a positive correlation between our ICT variables (IUI and MCS) and banking stability, suggesting that ICT positively impacts the stability of the banking system.

We estimate our model with the system GMM that corrects for measurement errors and simultaneity problems. More stable banking system can yield more potentialities for a higher economic growth. Highly growing economies could be more inflationary. SGMM method corrects for these problems and offers robust results. We used the Arellano and Bover (1995) approach to remedy for the weak instruments problem by considering both the lagged series and their lagged differences as instruments. Second and higher orders of the lagged endogenous variables are used as instruments. We implemented Sargan test of over identification and test for absence of AR (2) in the estimated models. Our models passed the tests as appropriate.

Our estimation methodology relies on three stages. First, we estimate the model for the full sample. Second, as evidenced in the literature, ICT variables do not behave in the same way when the level of countries' income is taken into consideration. Therefore, we split our full sample into two different subsamples, namely the high-income and the low-income countries subsamples. We estimate our models for these two subsamples to check for the stability of our relationship through different national income levels. We also check for the potential existence of a nonlinear relationship between ICT usage and banking stability.

\section{Results and Discussion}

Estimation outcomes of the relationship between ICT variables and banking crisis variable for the full sample and the subsamples are presented in Table 1. The first and the second column display the estimation results for the two ICTs proxies, 
namely the percentage of the population using the internet (IUI) and mobile cellular phone subscription $(M C S)$, respectively.

Results show that both variables of interest present a positive coefficient, suggesting that ICT use is correlated with more banking stability. Although this impact will be further investigated in the upcoming paragraphs, a preliminary explanation of this result lies in the context of the economics of digitalization. More digitalized economies usually produce better outcomes in a range of aspects of economic activity in general and on the banking activity specifically. This suggests that more use

Table 1 ICT and banks' financial stability: linear Relationship

\begin{tabular}{|c|c|c|c|c|c|c|}
\hline & \multicolumn{2}{|l|}{ Full sample } & \multicolumn{2}{|l|}{ High income } & \multicolumn{2}{|l|}{ Low income } \\
\hline & (1) & (2) & (3) & (4) & (5) & (6) \\
\hline Dep. lag1 & $\begin{array}{l}1.020 * * * \\
(0.0389)\end{array}$ & $\begin{array}{l}0.927 * * * \\
(0.0347)\end{array}$ & $\begin{array}{l}0.825 * * * \\
(0.0635)\end{array}$ & $\begin{array}{l}0.842 * * * \\
(0.0603)\end{array}$ & $\begin{array}{l}1.309 * * * \\
(0.125)\end{array}$ & $\begin{array}{l}0.680 * * * \\
(0.0756)\end{array}$ \\
\hline IUI & $\begin{array}{l}0.00686^{* * *} \\
(0.00167)\end{array}$ & & $\begin{array}{l}0.0131 * * * \\
(0.00433)\end{array}$ & & $\begin{array}{l}0.0108 * * \\
(0.00527)\end{array}$ & \\
\hline MCS & & $\begin{array}{l}0.00300 * * * \\
(0.000981)\end{array}$ & & $\begin{array}{l}0.0101 * * * \\
(0.00251)\end{array}$ & & $\begin{array}{l}0.00413^{\text {*** }} \\
(0.00149)\end{array}$ \\
\hline NIM & $\begin{array}{l}0.208^{* *} \\
(0.0850)\end{array}$ & $\begin{array}{l}0.270 * * * \\
(0.0712)\end{array}$ & $\begin{array}{l}0.368 * * * \\
(0.122)\end{array}$ & $\begin{array}{l}0.449 * * * \\
(0.124)\end{array}$ & $\begin{array}{l}0.113^{*} \\
(0.0615)\end{array}$ & $\begin{array}{l}0.385 * * * \\
(0.0988)\end{array}$ \\
\hline CONC & $\begin{array}{l}-0.00610 * * * \\
(0.00220)\end{array}$ & $\begin{array}{l}-0.00884 * * * \\
(0.00221)\end{array}$ & $\begin{array}{l}0.000737 \\
(0.00947)\end{array}$ & $\begin{array}{l}0.0125 \\
(0.00978)\end{array}$ & $\begin{array}{l}-0.00168 \\
(0.00290)\end{array}$ & $\begin{array}{l}-0.00934 * * \\
(0.00436)\end{array}$ \\
\hline ROA & $\begin{array}{l}0.224 * * * \\
(0.0423)\end{array}$ & $\begin{array}{l}0.357 * * * \\
(0.0760)\end{array}$ & $\begin{array}{l}0.171 * * \\
(0.0808)\end{array}$ & $\begin{array}{l}0.178 * * \\
(0.0800)\end{array}$ & $\begin{array}{l}0.129 * * \\
(0.0545)\end{array}$ & $\begin{array}{l}0.163 * * * \\
(0.0362)\end{array}$ \\
\hline CIR & $\begin{array}{l}-0.0107 * * * \\
(0.00365)\end{array}$ & $\begin{array}{l}-0.00678 \\
(0.00584)\end{array}$ & $\begin{array}{l}-0.0255^{* * *} \\
(0.00693)\end{array}$ & $\begin{array}{l}-0.0222 * * * \\
(0.00713)\end{array}$ & $\begin{array}{l}-0.0190 * * * \\
(0.00409)\end{array}$ & $\begin{array}{l}-0.0174 * \\
(0.0105)\end{array}$ \\
\hline GDP & $\begin{array}{l}0.00340 \\
(0.0120)\end{array}$ & $\begin{array}{l}0.0340 * * * \\
(0.0131)\end{array}$ & $\begin{array}{l}0.0321 \\
(0.0204)\end{array}$ & $\begin{array}{l}0.0112 \\
(0.0201)\end{array}$ & $\begin{array}{l}0.0735 * * * \\
(0.0199)\end{array}$ & $\begin{array}{l}0.0251 \\
(0.0218)\end{array}$ \\
\hline INF & $\begin{array}{l}-0.00469 \\
(0.00304)\end{array}$ & $\begin{array}{l}-0.00447 \\
(0.00439)\end{array}$ & $\begin{array}{l}-0.0628 * * * \\
(0.0152)\end{array}$ & $\begin{array}{l}-0.0887 * * * \\
(0.0213)\end{array}$ & $\begin{array}{l}-0.00589 \\
(0.00847)\end{array}$ & $\begin{array}{l}-0.00851 \\
(0.00898)\end{array}$ \\
\hline $\mathrm{COC}$ & $\begin{array}{l}0.231 \\
(0.144)\end{array}$ & $\begin{array}{l}0.446 * * * \\
(0.114)\end{array}$ & $\begin{array}{l}0.181 \\
(0.332)\end{array}$ & $\begin{array}{l}0.551 \\
(0.442)\end{array}$ & $\begin{array}{l}0.705 \\
(0.599)\end{array}$ & $\begin{array}{l}1.001 * * \\
(0.428)\end{array}$ \\
\hline Constant & $\begin{array}{l}1.771 * * * \\
(0.606)\end{array}$ & $\begin{array}{l}0.948 \\
(0.622)\end{array}$ & $\begin{array}{l}3.554 * * * \\
(1.092)\end{array}$ & $\begin{array}{l}2.560 * * \\
(1.064)\end{array}$ & $\begin{array}{l}0.292 \\
(0.853)\end{array}$ & $\begin{array}{l}-1.050 \\
(1.168)\end{array}$ \\
\hline Sargan test & $69.69(0.18)$ & $72.49(0.11)$ & $35.74(0.38)$ & $34.94(0.42)$ & 7.70(0.99) & $20.60(0.99)$ \\
\hline $\mathrm{AR}(1)$ & 0.000 & 0.000 & 0.001 & 0.001 & 0.011 & 0.004 \\
\hline AR (2) & 0.373 & 0.246 & 0.278 & 0.367 & 0.82 & 0.728 \\
\hline Observations & 2,246 & 2,260 & 1,406 & 1,418 & 681 & 682 \\
\hline Number of id & 113 & 113 & 76 & 76 & 37 & 37 \\
\hline
\end{tabular}

Figures in parentheses are standard errors. Sargan test of over-identifying restrictions. AR (1) and AR (2) tests for the second order autocorrelation in the differenced residuals. $\mathrm{P}<0.10$. $* \mathrm{P}<0.05$. $* * \mathrm{P}<0.01$. $* * * \mathrm{P}<0.001$. Estimation outcomes displayed after taking into account country and period fixed effects 
of internet and more broadly ICTs means a higher automation of banking activities such as credit scoring and making decisions on whether to lend to both consumers and firms. This will reduce human intervention and reduce the power of people. By automating these processes, both well-connected and non-connected customers will be treated equally and fairly. This will contribute to reducing the possibility of non-performing loans or any excessive risk-taking by banks' managers and therefore reduce the fragility of the banking system. Automation of the prudential procedures would optimize the decision process in banks. Use of Open Banking can help create value for banks and therefore render them more resilient.

All remaining variables present the expected signs. For example, the net interest margin and the return on assets have positive coefficients, showing that more banking profitability is correlated with more banking stability and therefore less banking crisis. Inflation does not seem to have a significant impact on banking stability for our sample of countries. Economic growth is positively and significantly correlated to banking stability for the second ICT variable, suggesting that better economic performance is associated with better profitability for banks and therefore with their resilience. Banking concentration produces a negative coefficient on the occurrence of banking crisis. This finding is therefore in line with the second strand of literature developed above. Consistent with the theoretical prediction, cost to income ratio produces a negative coefficient in the estimation, suggesting that better cost management is correlated with banking stability.

More findings in our estimation show that the corruption coefficient is not significant in this set of estimations, suggesting that corruption cannot explain the banking stability/instability on its own.

As evidenced in the literature, the impact of information and communication technology on different economic variables can produce different outcomes depending on countries' level of income. When estimating our model for our subsamples, our findings show different results depending on countries levels' of income (Ben Ali and Gasmi, 2017). The high-income countries subsample shows, as previously, the same coefficients for both ICT variables in the sense that they are still producing a positive impact for the stability of the banking system. With some exceptions compared with the estimation for the full sample, all remaining variables present the previous signs and significance. However, although presenting the same sign as previously, concentration is not significant for the banking stability of the developed countries. This result stems from the fact that banks in developed countries are more closely monitored and regulated and the level of their concentration does not really matter for the stability of the banking system as a whole. Economic growth is also not significant in explaining banking stability. This result is in line with the previous one in the sense that more or less growth in these developed countries is not really correlated negatively or positively with the stability of the banking system. Factors that contribute to the stability of banking systems in these countries go beyond inflation or economic growth potentialities. 
Table 2 ICT and banks' financial stability: The Non-Linear relationship

\begin{tabular}{|c|c|c|c|c|}
\hline & \multicolumn{2}{|l|}{ High Income } & \multicolumn{2}{|l|}{ Low Income } \\
\hline & (3) & (4) & (5) & (6) \\
\hline Dep. lag1 & $\begin{array}{l}0.688 * * * \\
(0.0928)\end{array}$ & $\begin{array}{l}0.880 * * * \\
(0.0959)\end{array}$ & $\begin{array}{l}0.721 * * * \\
(0.0693)\end{array}$ & $\begin{array}{l}0.677 * * * \\
(0.0848)\end{array}$ \\
\hline IUI & $\begin{array}{l}-0.0671^{* * *} \\
(0.0245)\end{array}$ & & $\begin{array}{l}-0.0327 * * * \\
(0.0106)\end{array}$ & \\
\hline IUI_sq & $\begin{array}{l}0.000712 * * * \\
(0.000241)\end{array}$ & & $\begin{array}{l}0.000879 * * * \\
(0.000179)\end{array}$ & \\
\hline MCS & & $\begin{array}{l}-0.0223 * \\
(0.0117)\end{array}$ & & $\begin{array}{l}-0.00860 * \\
(0.00448)\end{array}$ \\
\hline MCS_sq & & $\begin{array}{l}0.000136 * * \\
(5.34 \mathrm{e}-05)\end{array}$ & & $\begin{array}{l}7.82 \mathrm{e}-05^{* * *} \\
(2.67 \mathrm{e}-05)\end{array}$ \\
\hline NIM & $\begin{array}{l}0.317 * * \\
(0.137)\end{array}$ & $\begin{array}{l}0.320^{*} \\
(0.169)\end{array}$ & $\begin{array}{l}0.128 \\
(0.0804)\end{array}$ & $\begin{array}{l}0.235^{* * * *} \\
(0.0900)\end{array}$ \\
\hline CONC & $\begin{array}{l}-0.0238^{* *} \\
(0.0101)\end{array}$ & $\begin{array}{l}0.00464 \\
(0.0111)\end{array}$ & $\begin{array}{l}-0.00798 * * * \\
(0.00215)\end{array}$ & $\begin{array}{l}-0.0191 * * * \\
(0.00609)\end{array}$ \\
\hline ROA & $\begin{array}{l}0.0689 \\
(0.0714)\end{array}$ & $\begin{array}{l}0.194 * * \\
(0.0878)\end{array}$ & $\begin{array}{l}0.0549 \\
(0.0526)\end{array}$ & $\begin{array}{l}-0.00944 \\
(0.0288)\end{array}$ \\
\hline CIR & $\begin{array}{l}-0.0336 * * * \\
(0.00792)\end{array}$ & $\begin{array}{l}-0.0260 * * * \\
(0.00823)\end{array}$ & $\begin{array}{l}-0.0171 * * * \\
(0.00301)\end{array}$ & $\begin{array}{l}-0.0525^{* * *} \\
(0.0143)\end{array}$ \\
\hline GDP & $\begin{array}{l}0.0646^{* * * *} \\
(0.0216)\end{array}$ & $\begin{array}{l}0.00325 \\
(0.0234)\end{array}$ & $\begin{array}{l}0.00266 \\
(0.0202)\end{array}$ & $\begin{array}{l}0.0121 \\
(0.0171)\end{array}$ \\
\hline INF & $\begin{array}{l}-0.0647 * * * \\
(0.0203)\end{array}$ & $\begin{array}{l}-0.0772 * * * \\
(0.0264)\end{array}$ & $\begin{array}{l}-0.00180 \\
(0.00537)\end{array}$ & $\begin{array}{l}-0.0283^{* *} \\
(0.0112)\end{array}$ \\
\hline $\mathrm{COC}$ & $\begin{array}{l}1.244 * * * \\
(0.300)\end{array}$ & $\begin{array}{l}0.657 \\
(0.690)\end{array}$ & $\begin{array}{l}0.465 * * \\
(0.225)\end{array}$ & $\begin{array}{l}2.521 * * * \\
(0.401)\end{array}$ \\
\hline Constant & $\begin{array}{l}8.209 * * * \\
(1.772)\end{array}$ & $\begin{array}{l}5.277 * * * \\
(1.533)\end{array}$ & $\begin{array}{l}1.411 \\
(0.975)\end{array}$ & $\begin{array}{l}3.284 * * \\
(1.632)\end{array}$ \\
\hline $\begin{array}{l}\text { Sargan test } \\
\text { AR (1) } \\
\text { AR (2) }\end{array}$ & $\begin{array}{l}16.72(0.97) \\
0.003 \\
0.251\end{array}$ & $\begin{array}{l}13.87(0.96) \\
0.002 \\
0.53\end{array}$ & $\begin{array}{l}17.92(0.94) \\
0.07 \\
0.083\end{array}$ & $\begin{array}{l}17.89(0.99) \\
0.017 \\
0.158\end{array}$ \\
\hline Observations & 1,406 & 1,418 & 681 & 682 \\
\hline Number of id & 76 & 76 & 37 & 37 \\
\hline
\end{tabular}

Figures in parentheses are standard errors. AR (1) and AR (2) tests for the second order autocorrelation in the differenced residuals. Sargan test of over-identifying restrictions. $\mathrm{P}<0.10$. $* \mathrm{P}<0.05$. ** $\mathrm{P}<0.01$. $* * * \mathrm{P}<0.001$. Estimation outcomes displayed after taking into account country and period fixed effects

Our methodology then consists of conducting a second set of estimations to look for the existence of a potential nonlinear relationship between ICT variables and the banking stability variable. Estimation outcomes presented in Table 2 show that the ICT linear term and the quadratic term present a negative and a positive sign, respectively, suggesting the existence of a nonlinear relationship between the ICTs variables and banking stability. This finding shows that ICT can have a positive impact only if 
a certain ICT threshold is reached. Indeed, the ICT linear variable displays a negative coefficient while its square term displays a positive and significant coefficient. This result is in line with the findings of a pillar study in the literature showing that the effectiveness of the use of ICT devices increases with the number of users. In a study by Grace et al. (2003), the authors argue that the importance of a telephone line increases exponentially as more and more users are connected to the network. This result shows that a certain threshold is required in order that the ICT can make a positive impact on the stability of the banking system. Below this threshold, no positive effect could be recorded. We compute this threshold according to the formula below where ICT in the formula stands for both IUI and MCS.

$$
\frac{d B Z}{d I C T}=0 \longrightarrow \beta_{1}+2 \beta_{2} I C T=0 \rightarrow I C T^{*}=\frac{-\hat{\beta}_{1}}{2 \hat{\beta}_{2}}
$$

Our calculations show that these thresholds for the high-income countries for the internet and the mobile variables are 47.12 and 81.99, respectively. As for the lowincome countries, these variables display a threshold of 54.99 and 18.60 , respectively. Mobile devices usage is more associated with banking stability than the internet in high-income countries. On the contrary, in low-income countries, internet access is more correlated with the banking stability than mobiles. This stems from the fact that in developing countries, connectivity is usually used through mobiles rather than other devices. However, in developing countries not all people have access to the mobile technology and connectivity is accessed mainly through other devises at home rather through mobiles.

Our last set of estimations will introduce an interaction variable in our model, between ICTs variables (IUI and MCS) and corruption (IUI*COC and MCS*COC). The objective is to see the nature of the interaction between these two variables in our specification.

Estimation outcomes reported in Table 3 show an interesting and pillar finding of this study. Indeed, the interaction variable for the internet and mobile variables (IUI*COC and MCS*COC) displays a positive and significant coefficient for both the high-income and low-income countries subsamples. This finding shows that the correlation of ICT with banking stability is higher when corruption is lower and lower when corruption is higher. Information and communication technologies can improve the stability of the banking system only when corruption is relatively low. This shows also that when corruption is endemic, ICT endowment is useless for the stability of the banking system.

\section{Conclusions and Policy Implications}

This study assesses the correlation between ICTs and banking stability while considering the interfering impact of corruption. We considered a sample of 113 countries over the period 1996-2017 and then looked at countries with different income 
Table 3 ICT and banks' financial stability: Interaction relationship

\begin{tabular}{|c|c|c|c|c|}
\hline & \multicolumn{2}{|l|}{ High income } & \multicolumn{2}{|l|}{ Low income } \\
\hline & (3) & (4) & (5) & (6) \\
\hline \multirow[t]{2}{*}{ Dep. lag1 } & $0.837 * * *$ & $0.908 * * *$ & $1.122^{* * *}$ & $0.791 * * *$ \\
\hline & $(0.0953)$ & $(0.0798)$ & $(0.136)$ & $(0.0695)$ \\
\hline \multirow[t]{2}{*}{ IUI } & & 0.000269 & $0.0342^{* * * *}$ & \\
\hline & & $(0.00310)$ & $(0.00837)$ & \\
\hline \multirow[t]{2}{*}{ IUI*COC } & & $0.00672 *$ & $0.0490 * * *$ & \\
\hline & & $(0.00392)$ & $(0.0130)$ & \\
\hline \multirow[t]{2}{*}{ MCS } & $0.00683 * * *$ & & & $0.00865 * * *$ \\
\hline & $(0.00167)$ & & & $(0.00274)$ \\
\hline \multirow[t]{2}{*}{$\mathrm{MCS} * \mathrm{COC}$} & $0.00614 *$ & & & $0.0140^{* * * *}$ \\
\hline & $(0.00358)$ & & & $(0.00516)$ \\
\hline \multirow[t]{2}{*}{ NIM } & $0.429 * * *$ & $0.409 * * *$ & 0.0925 & $0.138^{*}$ \\
\hline & $(0.138)$ & $(0.130)$ & $(0.0646)$ & $(0.0817)$ \\
\hline \multirow[t]{2}{*}{ CONC } & -0.00793 & -0.0128 & $-0.00569^{* *}$ & $-0.0142^{* * * *}$ \\
\hline & $(0.00891)$ & $(0.00844)$ & $(0.00286)$ & $(0.00475)$ \\
\hline \multirow[t]{2}{*}{ ROA } & $0.279 * *$ & $0.104 * * *$ & -0.0215 & 0.0781 \\
\hline & $(0.124)$ & $(0.0318)$ & $(0.0381)$ & $(0.0505)$ \\
\hline \multirow[t]{2}{*}{ CIR } & $-0.0214 * * *$ & $-0.0269^{* * *}$ & $-0.0209 * * *$ & $-0.0280^{* * * *}$ \\
\hline & $(0.00726)$ & $(0.00746)$ & $(0.00417)$ & $(0.00871)$ \\
\hline \multirow[t]{2}{*}{ GDP } & 0.00344 & 0.0280 & $0.0492 * *$ & -0.00116 \\
\hline & (0.0234) & (0.0214) & (0.0197) & $(0.0217)$ \\
\hline \multirow[t]{2}{*}{ INF } & $-0.0543^{* * *}$ & $-0.0627 * * *$ & -0.00655 & -0.0126 \\
\hline & $(0.0151)$ & $(0.0180)$ & $(0.00658)$ & $(0.00819)$ \\
\hline \multirow[t]{2}{*}{$\mathrm{COC}$} & $1.340 * * *$ & $0.658^{*}$ & $1.526^{* * *}$ & $1.188 * * *$ \\
\hline & $(0.366)$ & $(0.393)$ & $(0.440)$ & $(0.309)$ \\
\hline \multirow[t]{2}{*}{ Constant } & $2.286^{*}$ & $4.604 * * *$ & 0.353 & $2.219^{*}$ \\
\hline & (1.293) & (1.279) & $(0.743)$ & (1.214) \\
\hline Sargan test & $24.49(0.60)$ & $17.71(0.96)$ & $7.50(0.99)$ & $18.69(0.979)$ \\
\hline AR (1) & 0.004 & 0.001 & $0 . .14$ & 0.007 \\
\hline AR (2) & 0.135 & 0.684 & 0.83 & 0.182 \\
\hline Observations & 1,418 & 1,406 & 681 & 682 \\
\hline Number of id & 76 & 76 & 37 & 37 \\
\hline
\end{tabular}

Figures in parentheses are standard errors. Sargan test of over-identifying restrictions. AR (1) and AR (2) tests for the second order autocorrelation in the differenced residuals. $\mathrm{P}<0.10$. $* \mathrm{P}<0.05$. ** $\mathrm{P}<0.01$. $* * * \mathrm{P}<0.001$. Estimation outcomes displayed after taking into account country and period fixed effects

levels to check the stability of the relationship across varying levels of income. It is worth noting here that our purpose was to test the correlation and not causation.

Estimation outcomes show that both ICT variables present a positive coefficient, suggesting that ICT technologies usage is correlated with less banking fragility. When estimating the interaction variable for the full sample, we show that ICT endowment and corruption act complementarily. Information and communication is 
associated with better stability in the banking system. More highly ICT-endowed countries are correlated with a better resilience of their banking systems.

Previous studies have shown that the impact of ICT on different economic variables is not the same for all countries but depends rather on their level of income and more broadly of economic development. Therefore, we estimate our model for two different subsamples of countries representing different levels of economic development. Estimation outcomes for the developed countries subsample confirm our previous findings. Our findings support the existence of a nonlinear relationship between ICTs usage and banking stability in the sense that a certain threshold of ICT endowment needs to be reached in order for ICT use to improve the level of banking stability.

Two main policy implications emerge from this study. Firstly, a way to curb the adverse effects of corruption on bank lending is to have an effective ICT infrastructure. Obviously, better ICT endowment can have various positive impacts on different economic factors, and especially on the stability of the banking system. Second, the threshold analysis suggests that it is not only a matter of ICTs endowment but that countries should target a certain level of ICT infrastructure to be able to benefit from the positive effect of these technologies.

\section{Appendix}

See Tables 4, 5, 6 .

Table 4 Summary statistics

\begin{tabular}{lllrll}
\hline Variables & Obs & Mean & Std. Dev & Min & Max \\
\hline BZscore & 2,486 & 14.0542 & 8.6450 & .01669 & 61.1642 \\
NIM & 2,486 & 4.5490 & 3.3604 & .0095 & 58.6299 \\
CONC & 2,486 & 68.3183 & 19.4925 & 17.1639 & 100 \\
ROA & 2,486 & 1.2313 & 2.3646 & -29.116 & 65.8374 \\
CIR & 2,486 & 56.4381 & 14.2773 & 19.895 & 218.087 \\
GDP & 2,486 & 3.8181 & 3.9054 & -21.594 & 34.4662 \\
INF & 2,486 & 8.5976 & 86.9661 & -8.5251 & 4145.106 \\
COC & 2,486 & .1744 & 1.0419 & -1.7222 & 2.4699 \\
IUI & 2,486 & 30.4116 & 29.8975 & 0 & 100 \\
MCS & 2,486 & 67.465867 .46584 & 53.4357 & 0 & 328.7904 \\
\hline
\end{tabular}




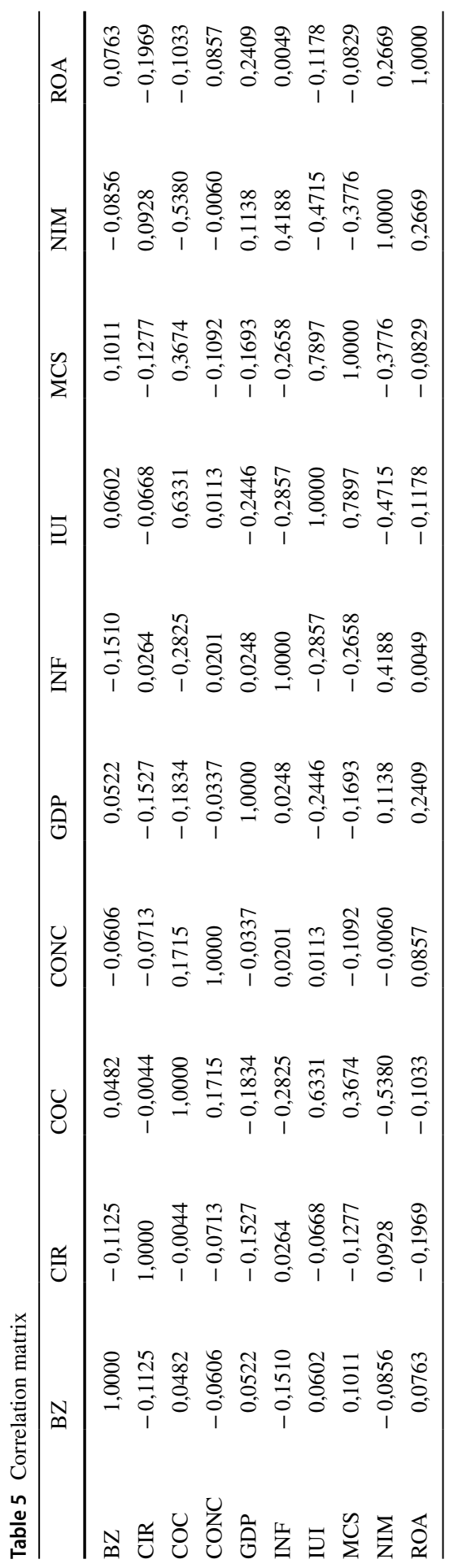


Table 6 List of countries

\begin{tabular}{|c|c|c|c|c|}
\hline Albania & Costa Rica & Hong Kong & Mauritania & Saudi Arabia \\
\hline Algeria & Croatia & Hungary & Mauritius & Senegal \\
\hline Angola & Cyprus & Iceland & Mexico & Singapore \\
\hline Armenia & Check Rep & India & Moldova & Slovak rep \\
\hline Australia & Cote d'Ivoire & Indonesia & Morocco & Slovenia \\
\hline Austria & Denmark & Ireland & Nepal & Spain \\
\hline Azerbaijan & Dominican & Israel & Netherlands & Sweden \\
\hline Bahamas & Ecuador & Italy & New Zealand & Switzerland \\
\hline Bahrain & Egypt & Japan & Nicaragua & Thailand \\
\hline Bangladesh & El Salvador & Jordan & Niger & Togo \\
\hline Barbados & Estonia & Kazakhstan & Nigeria & Trinidad \\
\hline Belarus & Ethiopia & Kenya & Norway & Tunisia \\
\hline Belgium & Finland & Korea rep & Oman & Turkey \\
\hline Benin & France & Kuwait & Pakistan & Uganda \\
\hline Bolivia & Gabon & Latvia & Panama & Ukraine \\
\hline Botswana & Georgia & Lithuania & Paraguay & United Kingdom \\
\hline Brazil & Germany & Luxembourg & Peru & United states \\
\hline Bulgaria & Ghana & Macao & Philippines & Uruguay \\
\hline Burkina Faso & Greece & Madagascar & Poland & Vietnam \\
\hline Burundi & Guatemala & Malawi & Portugal & Yemen \\
\hline Chile & Guyana & Malaysia & Qatar & Zambia \\
\hline China & Haiti & Mali & Romania & \\
\hline Colombia & Honduras & Malta & Russia & \\
\hline
\end{tabular}

Funding Open Access funding provided by the Qatar National Library.

Open Access This article is licensed under a Creative Commons Attribution 4.0 International License, which permits use, sharing, adaptation, distribution and reproduction in any medium or format, as long as you give appropriate credit to the original author(s) and the source, provide a link to the Creative Commons licence, and indicate if changes were made. The images or other third party material in this article are included in the article's Creative Commons licence, unless indicated otherwise in a credit line to the material. If material is not included in the article's Creative Commons licence and your intended use is not permitted by statutory regulation or exceeds the permitted use, you will need to obtain permission directly from the copyright holder. To view a copy of this licence, visit http://creativecommons.org/licen ses/by/4.0/.

\section{References}

Arellano, M., and O. Bover. 1995. Another look at the instrumental variable estimation of errorcomponents models. Journal of Econometrics 68 (1): 29-51.

Asongu, S.A., and N. Biekpe. 2018. ICT, information asymmetry and market power in African banking industry. Research in International Business and Finance 44: 518-531. 
Athanasoglou, P.P., S.N. Brissimis, and M.D. Delis. 2008. Bank-specific, industry-specific and macroeconomic determinants of bank profitability. Journal of International Financial Markets, Institutions and Money 18 (2): 121-136.

Avoma, D., H. Nkengfacka, H. KaffoFotiob, and A. Totouoma. 2020. ICT and environmental quality in Sub-Saharan Africa: effects and transmission channels. Technological Forecasting \& Social Change 155: 2 .

Balkin, J.M. 2004. Digital speech and democratic culture: A theory of freedom of expression for the information society. New York University Law Review 79 (1): 1-55.

Barth, J., G. Caprio, and R. Levine. 2007. The microeconomic effects of different approaches to bank supervision. In Political institutions and financial development, ed. S. Haber, D. North, and B. Weingast, 156-188. Stanford: Stanford University Press.

Ben Ali, M.S. 2020. Does ICT promote democracy similarly in developed and developing countries? A linear and nonlinear panel threshold framework. Telematics and Informatics 2: 2.

Ben Ali, M.S., and A. Gasmi. 2017. Does ICT diffusion matter for corruption? An economic development perspective. Telematics and Informatics 34 (8): 1445-1453.

Ben Ali, M.S., I. Timoumi, and R. Zeitun. 2018. Banking concentration and financial stability: new evidence from developed and developing countries. Eastern Economic Journal 44 (1): 1-18.

Ben Ali, M.S., F. Fehima, and R. Nouira. 2020. How does corruption undermine banking stability? A threshold nonlinear framework. Journal of Behavioral and Experimental Finance 27: 2.

Ben Khediri, K., M.S. Ben Ali, and H. Ben Khediri. 2010. Bank-specific, industryspecific and macroeconomic determinants of African Islamic banks' profitability. Int. J. Bus. Manag. Sci. 3 (1): 38-58.

Bretschger, L., V. Kappel, and T. Werner. 2012. Market concentration and the likelihood of financial crises. J. Bank. Financ. 36 (12): 3336-3345.

Charumilind, C., R. Kali, and Y. Wiwattanakantang. 2006. Connected lending: Thailand before the financial crisis. The Journal of Business 79 (1): 181-218.

Chiaramonte, L. Hong., F. Liu, F. Poli, and M. Zhou. 2016. How accurately can z-score predict bank failure? Financial Markets, Institutions \& Instruments 25 (5): 333-360.

Cubillas, E., and N. Suárez. 2013. Bank market power after a banking crisis: some international evidence. The Spanish Review of Financial Economics 11: 13-28.

Demirgüç-Kunt, A., and R. Levine. 2001. Financial structure and economic growth. A cross-country comparison of banks, markets, and development. Cambridge: MIT Press.

Drezner, D.W., and H. Farrell. 2008. Blogs, politics and power. Public Choice 134 (1/2): 15-30.

Edquist, H., and M. Henreksonb. 2017. Swedish lessons: how important are ICT and R\&D to economic growth? Structural Change and Economic Dynamics 42: 1-12.

Fernández, A.I., F. González, and N. Suárez. 2016. Banking stability, competition and economic volatility. Journal of Financial Stability 22: 101-120.

Grace, J., Kenny, C., Qiang, C., Liu, J., Reynolds, T., 2003. Information and communication technologies and broad base development: a partial review of the evidence. World Bank Work. Paper no.12.

Hardy, A.P. 1980. The role of the telephone in economic development. Telecommunications Policy 4 (4): 278-286.

Hwanga, W.S., and J. Shinb. 2017. ICT-specific technological change and economic growth in Korea. Telecommunications Policy 41: 282-294.

Jin, S., and C. Moon Cho. 2015. Is ICT a new essential for national economic growth in an information society? Government Information Quarterly 32: 253-260.

Klomp, J.. De., and J. Haan. 2015. Bank regulation and financial fragility in developing countries: Does bank structure matter? Review of Development Finance 5 (2): 82-90.

La Porta, R., F. Lopez-de Silanes, and G. Zamarripa. 2003. Related lending. The Quarterly Journal of Economics 118 (1): 231-268.

Laeven, L., and Valencia, F. (2018) Systemic banking crises revisited, IMF Working Papers 18/206, International Monetary Fund.

Lepetit, L., and F. Frank. 2015. Bank insolvency risk and Z-score measures: a refinement. Finance Research Letters 13: 214-224.

Lepetit, L., and F. Strobel. 2013. Bank insolvency risk and time-varying Z-score measures. Journal of International Financial Markets Institutions and Money 25: 73-87.

Mushtaqa, R. and Bruneau, C. (2019). Microfinance, financial inclusion and ICT: Implications for poverty and inequality, Technology in Society, 59.

Niebel, T. 2018. ICT and economic growth-Comparing developing, emerging and developed countries. World Development 104: 197-211. 
Rodríguez-Crespoa, E., and I. Martínez-Zarzoso. 2019. The effect of ICT on trade: Does product complexity matter? Telematics and Informatics 41: 182-196.

Rojas and Suarez (2001). Rating banks in emerging markets: What credit agencies should learn from financial indicators, Institute for International Economics working paper 6.

Stewart, R., and M. Chowdhury. 2021. Banking sector distress and economic growth resilience: asymmetric effects. The Journal of Economic Asymmetries 24: 2.

Tchamyoua, V.S., G. Erreygersa, and D. Cassimonc. 2019. Inequality, ICT and financial access in Africa. Technological Forecasting \& Social Change 139: 169-184.

Wang, Y., and J. Li. 2017. ICT's effect on trade: Perspective of comparative advantage. Economics Letters 155: 96-99.

Xiping Li, X. Tripe, D. Malone, C. and David D. (2020). Measuring systemic risk contribution: The leave-one-out z-score method, Finance Research Letters, https://www.sciencedirect.com/science/ article/abs/pii/S1544612319303149?via\%3Dihub

Publisher's Note Springer Nature remains neutral with regard to jurisdictional claims in published maps and institutional affiliations. 